\title{
Nietzsche on Magnanimity, Greatness, and Greatness of Soul
}

To appear in Virtues of Greatness: Approaches to the Past and Present of Magnanimity, ed. Sophia Vasalou (Oxford University Press)

Andrew Huddleston

Birkbeck, University of London

DRAFT 30 August 2018

\section{$\underline{\text { I. Introduction }}$}

Nietzsche occasionally uses terms such as Großmuth (GS, 49) that get rendered in English as "magnanimity." When he does, he is picking out something like its current meaning, namely that of being generous and forgiving. This sort of magnanimity in the narrow sense is something Nietzsche regards as a virtue. That may come as a surprise to those who operate with the caricature that he has no admiration for such things, preferring crude egoism and vengeance. While this passing praise of "magnanimity" in the narrow sense is important to recognize, it is a fairly minor note in Nietzsche's work. In bringing Nietzsche into dialogue with the tradition of thinking about the virtue of magnanimity, we do better if we harken back to the Aristotelian "crowning" virtue of megalopsychia (often translated as "magnanimity") and consider what the corresponding Nietzschean notion might be.

Nietzsche, like Aristotle, is centrally concerned with the idea of greatness of soul in his moral psychology and ethics. Given its present Christian connotations, that word "soul" might seem odd in Nietzsche's mouth. Yet when it comes to notions of the soul, Nietzsche is concerned that we not throw out the baby with the metaphysical bathwater. He is, to be sure, skeptical of what he sees as the "calamitous atomism" about the "soul" propagated by Christianity and some of its forbearers (e.g., Plato in the Phaedo) - the conception of "the soul as something indestructible, eternal, indivisible, as a monad, as an atomon: this belief," 
Nietzsche says, "ought to be expelled from science!" (BGE, I2). But he goes on to add right after: "Between ourselves, it is not at all necessary to get rid of 'the soul' at the same time, and thus to renounce one of the most ancient and venerable hypotheses... [t] $]$ he way is open for new versions and refinements of the soul-hypothesis; and such conceptions as 'mortal soul,' and 'soul as subjective multiplicity', and 'soul as social structure of the drives and affects,' want henceforth to have citizens' rights in science (BGE, I2).

In what follows, I will be exploring this notion of greatness of soul in Nietzsche and how it relates to Nietzschean greatness in general. For few philosophers is human greatness as paramount as it is for Nietzsche (UM, III:6). Greatness, for him, seems to take precedence over ordinary moral goodness. He is disdainful of the herdish values of compassion and humility, and in their place, he especially celebrates values that are associated with and realized by certain exceptional great individuals. Nietzsche, importantly, does not see great individuals just as means to other things that are of value-symphonies, philosophical works, and the like. Rather, he sees them as instantiating certain values themselves, in the sort of excellent characteristics they have and in the sort of impressive lives they lead. They are, for

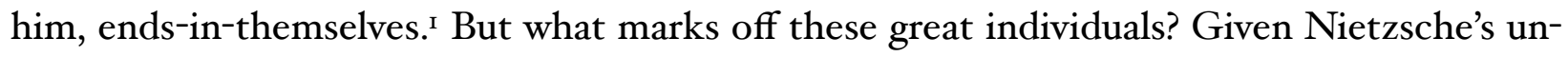
systematic style of presentation, we do not get a strictly delineated account. We instead get examples of great individuals, and various scattered comments about some characteristic features of human greatness. In this paper, I will seek to give an indication of Nietzsche's views on these issues, with a particular emphasis on thinking about greatness of soul, that is, the broadly-speaking psychical characteristics that are both conducive to and constitutive of

\footnotetext{
I This is not to say that all that is of value for Nietzsche are great individuals and their individual achievements. Nietzsche, as I argue elsewhere, also takes whole cultures to be valuable for their own sake. See Andrew Huddleston, Nietzsche on the Decadence and Flourishing of Culture (Oxford: Oxford University Press, 2019).
} 
exceptional flourishing as Nietzsche conceives it. In sketching the features that are salient for Nietzsche, I hope, in conjunction with the other papers in the volume, to indicate Nietzsche's commonalities and divergences with a broader strand of thinking, stemming from receptions of Aristotle's megalopsychia.

The paper will proceed as follows: After mentioning a few of Nietzsche's salient examples of great individuals, I will work through, and comment on, what he notes as some of the central marks of greatness. ${ }^{2}$ I then turn to a few reflections on Nietzsche's relation to Aristotle. In some work on Nietzsche, as well as in recent literature on the virtues, there has been dissatisfaction with Walter Kaufmann's influential suggestion that the Nietzschean great person is similar to the Aristotelian megalopsychos. While we should recognize that there are key differences between Nietzsche and Aristotle-and Kaufmann never claimed the parallel was exact $—$ we should not exaggerate these differences either, particularly not on the assumption that Nietzsche is a kind of crude irrationalist. Kaufmann's suggestion, I will argue, remains an enlightening way of situating Nietzsche's thought on this topic. But that said, there is another major point of divergence between Nietzsche on the one hand and Aristotle and other figures on the other. In the core of the tradition of thinking about greatness of soul, it will be thought to go hand-in-hand with moral goodness. Nietzsche, by contrast, seems to regard there as being an important tension between morality and the sort of human greatness he celebrates. I discuss, in conclusion, a few ways of understanding this

\footnotetext{
2 I focus primarily on material from the latter part of Nietzsche's career. There was undoubtedly some degree of development of Nietzsche's ideas on this topic from The Birth of Tragedy and the Untimely Meditations of the I870s to the final works of I888, such as Ecce Homo. One salient difference is in the figures he admires: Wagner and Schopenhauer are much lauded in Nietzsche's early works, but drop out of favor in his later works. Was this the result of Nietzsche's standards of greatness and ideas about it themselves changing, or simply his interpretation and assessment of these people? I suspect it is mostly the latter, though considerations of space preclude me from exploring in detail the way in which his views may have evolved. This would require, in particular, a more detailed analysis and treatment of the Untimely Meditations, and comparison of it with later works, than I am able to offer in this paper.
} 
tension and its implications for Nietzsche's relation to the main strand of thinking about this topic.

\section{Exemplars and Preliminaries}

It will be useful to begin by mentioning a few of the figures that Nietzsche singles out for praise as exemplars of human greatness. Some prime examples include Goethe (TI, "Skirmishes," 49), Leonardo da Vinci (BGE, 200), Raphael (TI, "Skirmishes," 9), Beethoven (UM, III: 3), and of course Nietzsche himself (EH). (False modesty, as we shall see, is not a virtue of great individuals.) Although Nietzsche's salient examples are creative and intellectual figures, ${ }^{3}$ he mentions some political figures as well, for example Cesare Borgia (TI, "Skirmishes," 37), Julius Caesar (BGE, 20o), Napoleon (GM, I:I6), and Frederick II (BGE, 200). When Nietzsche describes or celebrates people as great, it is often unclear whether he means that they are great of soul, or simply (or perhaps in addition) people who are great in virtue of having momentous influence, in, for example, putting their stamp decisively on history. My focus in this paper is primarily on greatness of soul, rather than this other sort of greatness, if we want to call it that (which might include Nietzsche's arch-villain St. Paul).4 Given how the two can come apart, it remains an open question whether even all of these individuals listed are great of soul. Clearly Goethe makes the cut, probably Beethoven, but

3 This point is stressed in Alexander Nehamas, Nietzsche: Life as Literature (Cambridge, MA: Harvard University Press, 1985), 227, and in Brian Leiter, Nietzsche on Morality (2nd ed.) (London and New York: Routledge, 2OI4), 98.

4 The German adjective groß, and to some extent the English "great," can, we must remember, merely characterize something as of considerable size or extent (the Great Famine, the Great Fire of London); it needn't indicate a positive normative assessment. Those with momentous influence are clearly "great" in the former sense in the influence they have. Whether they are in the latter sense is more contentious. 
with some of the others it is less clear. Socrates and St. Paul exert a tremendous influence, but they are, in Nietzsche's (perhaps tendentious) eyes, not great of soul.5

What are the psychical features of these sorts of individuals? Again, Nietzsche is never very systematic, but, across a range of passages, he makes various suggestions. But does this mean that there is a set of characteristics that they all have in common? This has been claimed in the recent secondary literature (albeit with a narrower range of features than those I give here) $)^{6}$, but it seems to me that this move is too hasty. Though I will go on to give some characteristics of greatness, it needn't be the case that every Nietzschean great individual has every one of these features listed. When Nietzsche says that something is great, or "belongs to greatness," or some such locution, it is never clear from the text whether the characteristics Nietzsche cites are sufficient and/or necessary for greatness, as opposed to generic characterizations or simply frequent marks of it. Moreover, it is not clear that there is meant to be a single ideal, as opposed to several. Nietzsche is a thinker highly sensitive to historical variability; the virtues conducive and constitutive of excellence in Homeric Greece, are not, one-for-one, those in late modern societies.7 Moreover, if we come to Nietzsche expecting a deeper philosophical explanation or argument of why these particular features redound to greatness, we are, in my view, likely to be disappointed. Interpreters, to this end, will sometimes ascribe to the so-called "will to power" a special priority

\footnotetext{
5 TI, "The Problem of Socrates" is a vitriolic attack not just on Socrates's philosophy, but on him personally as decadent and sick. Paul, likewise, is characterized as animated by hatred (A, 42), a clear sign of the workings of poisonous ressentiment in his psychological economy. Whatever wide influence their doctrines have, these two people are not paragons of Nietzchean virtue.

${ }^{6}$ Leiter, Nietzsche on Morality; Patrick Hassan, "Nietzsche on Human Greatness," Fournal of Value Inquiry 51:293(2017) 3 IO.

7 Simon Townsend,"Beyond the Myth of the Nietzschean Ideal Type," European Fournal of Philosophy 25, No. 3 (2017), 617-37.
} 
and reconstruct Nietzsche's ideas so as to seek to give it this unifying explanatory role. ${ }^{8} \mathrm{I}$ myself am more skeptical about the exegetical and philosophical merits of this will-to-power centered approach, and thus do not adopt it here. Nietzsche, in my view, is not a systematic thinker who argues from a single master value, or from an essentialist conception of human nature, to a view about human excellence (or anything else). What he gives us instead is a vision, which we must piece together from snippets of text, of what sorts of people and traits are especially admirable. Whether that vision persuades, or resonates, will likely depend on what values we hold, rather than on any argument Nietzsche gives for it.

Work on this topic has sometimes been framed in response to Alexander Nehamas, who claimed in his 1985 book Nietzsche: Life as Literature that Nietzsche does not offer any "descriptions of what an ideal person or an ideal life would be like." It has been pointed out in reply that Nehamas's contention is in fact incorrect; Nietzsche gives a number of descriptive characterizations of such people and lives in his works. But nonetheless, I think there is an important grain of truth to Nehamas's skepticism. Nietzsche's descriptions of his ideal of greatness do not provide us with belpfully regulative necessary and sufficient conditions. This is because Nietzsche does not specify conditions for how to be great, in such a way that observers could look to these conditions and the person at issue and easily settle the question of whether someone is great. The conditions just cannot be specified in enough detail so that it becomes an easy question, brooking no debate, whether someone meets them. It will typically involve contentious interpretation. ${ }^{10}$

\footnotetext{
8 One philosophically-sophisticated such attempt is to be found in John Richardson, Nietzsche's System (Oxford: Oxford University Press, 1996).

9 Nehamas, Nietzsche: Life as Literature, 8. Those responding include Leiter, Nietzsche on Morality, 93 and Hassan, "Nietzsche on Human Greatness," 295.

ro Here Nehamas's extended analogy of lives to artworks is a helpful one. See Nietzsche: Life as Literature.
} 
But issues of this sort aside, this examination of characteristics will nonetheless provide us with some important insight into Nietzsche's views, even if it is not a kind of rigid rubric. To that end, I will list a number of these characteristic features, and make a few brief comments on them. Before we proceed, an initial caveat is in order regarding pronouns and gender. All of Nietzsche's examples of great individuals are men, and most of his remarks concerning women are shockingly misogynistic. Regrettable though that may be, this makes the masculine pronoun the appropriate one in describing his view, and that is what I shall do in what follows.

\section{The Characteristics of Nietzschean Greatness and Greatness of Soul}

\section{Independent, to the point of being solitary.}

Describing the human beings who will appear in a more "virile, warlike" age, he says that they are those who are "silent, lonely, resolute, and content and constant in invisible activities" (GS, 283). The "concept of greatness entails... wanting to be by oneself, being able to be different, standing alone and having to live independently" (BGE, 2I2). He is someone who is "always in his own company, whether he associates with books, human beings, or landscapes" (EH, "Wise," 2). As with many things Nietzsche mentions, this characteristic is both a sign of greatness and an enabler of it. In living independently, one maintains distance from received opinions, and finds the peace and freedom from distraction to pursue significant projects.

Focused in pursuit of a goal. 
Great individuals are single-minded in their focus on these sorts of significant projects. These are the people who want to make a lasting stamp on the world, whether by writing novels, composing symphonies, or by building empires. Whereas others are pulled in various directions, or fritter away their time, great individuals stay on course. Nietzsche, describing himself in this regard, says he is "well disposed toward moralities which goad me to do something and to do it again, from morning till evening, and then to dream of it at night, and to think of nothing except doing this well, as well as $I$ alone can do it (GS, 304).

\section{Self-disciplined.}

Great individuals exercise strict discipline on themselves, a sort of self-control (TI, "Skirmishes," 49). They do not simply give free reign to their passing desires and impulses, but hold them in check sometimes. It might be nice to stay in the warm bed an extra hour in the morning, but this would squander productive time for work, so the great individual might force himself up for early writing, after dousing his face in icy cold water. Although Niet- $^{-}$ zsche abhors asceticism for asceticism's sake, he is not against asceticism and renunciation when it is done in furtherance of a worthy goal. If you are dousing your face in cold water because this will invigorate you for the day, that is a very different matter from doing it because you believe you, as a sinner, deserve no better (GM, III:9). Maintaining this discipline requires a certain "hammer-hardness" (BGE, 225) of being able to withstand suffering when necessary. "The discipline of suffering, of great suffering — do you not know that only this discipline has created all enhancements of man so far? (BGE, 225). (See also BGE, I88).

\section{Viewing others through the lens of one's project}


Because of this intense commitment, other people will be viewed primarily with regard to whether they are a help or a hindrance to what the great individual is seeking to accomplish. "A human being who strives for something great considers everyone he meets on his way either as a means or a delay and obstacle—or as a temporary resting place" (BGE, 273).

\section{Having a certain hardness against others}

One must even have a certain degree of apparent callousness: "Who will attain anything great if he does not find in himself the strength and the will to inflict great suffering? Being able to suffer is the least thing; weak women and even slaves often achieve virtuosity in that. But not to perish of internal distress and uncertainty when one inflicts great suffering and hears the cry of this suffering - that is great, that belongs to greatness" (GS, 325). This is a chillingly disconcerting quotation, calling to mind, with the benefit of historical hindsight, hardened concentration camp guards. But it is important to note that less unsavory things (indeed morally heroic ones) could meet this condition too. An acquaintance of mine, who is a physician and experienced mountain climber, once did an appendectomy on someone in desperate need during a climb on K2. I've not heard the details of the story in full detail, but imagine, given the minimal anesthetics available, that the operation must have been $\mathrm{ex}^{-}$ tremely painful, and no doubt provoked great cries from the suffering patient. To persist in the face of this takes great resolve, but it was what needed doing.

\section{Magnanimity}

Despite this hardness against others, one will not take vengeance against them for vengeance's sake. Nietzsche describes the person of magnanimity (Großmuth) as one who has 
the possibility of revenge, but "drain[s] it in his imagination," rising above it and forgiving the enemy (GS, 49; Cf., GS, 340) (Nietzsche suggests that this is because he becomes nauseated at this vengeful state, perhaps as something beneath him.) Even more extreme is the case of Mirabeau and those like him, who are so far above the slights done to them that they simply brush them off and forget about them (GM, I:IO).

\section{Resilient in the face of difficulties}

We inevitably face various difficulties. The great individual is someone able to cope with these as they come. He "guesses what remedies avail against what is harmful; he exploits bad accidents to his advantage; what does not kill him makes him stronger" (EH, "Wise," 2; Cf., TI, "Maxims," 8). After a setback or a defeat, some may slink away, or collapse into depression. But the great individual will treat this as an encouragement to go on- - to, as it were, get back in the saddle and try again or to move on to something else significant.

\section{Seeking obstacles and challenges to be overcome}

Indeed, it is not just that the great person waits for challenges and then copes with them when and as they come. He actively seeks out challenges, at least in certain domains. He is, as Nietzsche says, one who is "bent on seeking in all things for what in them must be overcome" (GS, 283). Such a person is not content to rest in comfort, but wants to try things that are new and difficult. If he has climbed one impressively high mountain, he will want to climb a yet higher one, or forgo the supplemental oxygen. If he has solved one difficult puzzle, he will want to try a more difficult one. This aspect of the view is related to the idea of the will 
to power, with the idea being that these challenges provide an opportunity to exercise the will to power. ${ }^{I I}$ One manifests one's power in the overcoming of such challenges.

\section{Willing to live dangerously}

Because of this emphasis on continual striving and overcoming, Nietzsche puts a premium on living dangerously. "[T]he secret for harvesting from existence the greatest fruitfulness and the greatest enjoyment is - to live dangerously! Build your cities on the slopes of Vesuvius! Send your ships into uncharted seas! Live at war with your peers and yourselves!” (GS, 283). Nietzsche of course means this beyond literal bodily peril. He also has in mind the idea of exposing oneself to the possibility of failure. It is in taking these sorts of risks that one makes possible many of the greatest sorts of accomplishments. In order to be willing to do this, the instinct of "self-preservation" must be suspended (TI, "Skirmishes," 44). This needn't mean that one is foolhardy or rashly self-destructive. But it does mean that one does not put safety and caution above all else.

\section{Instinctively drawn toward healthy courses of action}

In some apparent tension with this idea of living dangerously and putting aside self-preservation is the idea that the great person seeks out healthy courses of action. Nietzsche suggests that such a person has a "taste only for what is good for him; his pleasure, his delight, cease where the measure of what is good for him is transgressed" (EH, "Wise" 2). How can

\footnotetext{
II There are a variety of exegetical issues concerning the will to power, which I will need to leave to the side. But at least one important aspect of the will to power is that it involves this seeking out and overcoming of obstacles and resistances. For further discussion, see Bernard Reginster, The Affirmation of Life: Nietzsche on Overcoming Nibilism (Cambridge, MA: Harvard University Press, 2006) and Paul Katsafanas, "Nietzsche's Philosophical Psychology," in the Oxford Handbook of Nietzsche, ed. Ken Gemes and John Richardson (Oxford: Oxford University Press, 2013). Exactly how far to take this is another matter.
} 
putting oneself in danger represent an instinctive choice towards the healthy? We need to remember that Nietzschean health, in its highest forms, is going to be bound up with strength, resilience, and vitality. The fact that one can expose oneself to danger, and yet get through it without being undone and with having accomplished something important, is a sign of health. That fact that one would need, or feel the need, to cocoon oneself away from any potential threat is a sign not of health but of sickness. The fact that one should focus on, or feel the need to focus on, mere self-preservation is a sign of a weaker nature; for a stronger person, such considerations would be decidedly secondary.

\section{Verschwendung}

Also somewhat in tension with being instinctively drawn to the healthy is the idea of self "Verschwendung," perhaps best rendered as "self-expending." Nietzsche writes: "The genius, in work and deed, is necessarily an expender: that he expends himself, that is his greatness" (TI, "Skirmishes," 44). Nietzsche draws comparisons here to pent-up explosives and to rivers flooding their banks. Thanks to this superabundant outpouring, at the limit the great individual may need to forgo even his own health and sacrifice himself in the service of his cause. But this is something Nietzsche sees as admirable and heroic in the "devotion to an idea, a great cause, a fatherland" that it displays (TI, "Skirmishes," 44 ).

\section{Resistance to stimuli}

The analogy to rivers flooding their banks and explosives can seem to deprive great individuals of any sort of agency. It can make it seem as if they are just a bundle of dispositions that can be triggered in the right circumstances. But this underplays the fact that Nietzsche 
thinks of them as characteristically able to step back and make a sensible decision about what to do: The great individual "reacts slowly to all kinds of stimuli, with that slowness which long caution and deliberate pride have bred in him: he examines the stimulus that approaches him..." (EH, "Wise," 2). This is strongly connected with the sort of self-discipline mentioned above. Weaker individuals, by contrast, cannot resist such "stimuli." They are far more reactive. This is not to say that the great have any kind of libertarian free will, but it is to make room for a kind of reflective dimension when it comes to human action and $\operatorname{agency.12}^{12}$

\section{Honest in their outlook}

The strength of spirit characteristic of great individuals is correlated with being able to bear reality unadulterated. "[S]trength of spirit," Nietzsche writes, might be "measured according to how much of the 'truth' one could still barely endure - or to put it more clearly, to what degree one would require it to be thinned down, shrouded, sweetened, blunted, falsified" (BGE, 39). For this reason, Nietzsche praises honesty [Redlichkeit] as an important virtue of free spirits (BGE, 227). "In the middle of an age with an unreal outlook, Goethe was a convinced realist" (TI, "Skirmishes," 49). He didn't need to live by the usual pieties and illusions.

\section{Life-affirming}

\footnotetext{
I2 Paul Katsafanas, The Nietzschean Self: Moral Pyschology, Agency, and the Unconscious (Oxford: Oxford University Press, 2016) makes this conscious, reflective dimension very central to action and agency. Others are more focused on the unconscious drives and their interrelation. See Ken Gemes, "Nietzsche on Free Will, Autonomy, and the Sovereign Individual," in Nietzsche on Freedom and Autonomy, ed. Ken Gemes and Simon May (Oxford: Oxford University Press, 2009) and John Richardson, "Nietzsche's Freedoms," in Nietzsche on Freedom and Autonomy, ed. Ken Gemes and Simon May (Oxford: Oxford University Press, 2009).
} 
Another key mark of the great individual is satisfaction with this life and world, rather than longing for another and allegedly better one. Such a person is one that Nietzsche will describe as life-affirming. At the extreme, one will not just be positively disposed to this life and world, but will love it in every dimension. Nietzsche speaks of the "ideal of the most highspirited, alive, and world-affirming human being who has not only come to terms and learned to get along with whatever was and is, but who wants what was and is repeated into all eternity, shouting insatiably $d a$ capo-not only to himself but to the whole play and spectacle" (BGE, 56).13 Similarly, Nietzsche writes, with reference to Goethe, that he "stands amid the cosmos with a joyous and trusting fatalism, in the faith that only the particular is loathsome, and that all is redeemed and affirmed in the whole- be does not negate any more. Such a faith, however, is the highest of all possible faiths: I have baptized it with the name of Dionysus (TI, "Skirmishes," 49). The Dionysian faith makes one favorably disposed to this life and world, even though it has some questionable and terrifying features.

\section{Cheerful/foyful}

In keeping with this basically affirmative attitude, the great individual will be someone who is fundamentally cheerful or joyful (TI, "Skirmishes," 49). There are of course people who are smilingly blithe in a self-satisfied way, and Nietzsche treats such people with scorn. ${ }^{14}$ The

\footnotetext{
13 Exactly what does it take to be life-affirming? Does one need to affirm absolutely everything? Or is it a more modest ideal? Does it follow that Nietzsche regards all such things as worthy of affirmation? I discuss matters further in Andrew Huddleston, "Affirmation, Admirable Overvaluation, and the Eternal Recurrence," in Nietzsche on Morality and Affirmation, ed. Daniel Came (Oxford: Oxford University Press, forthcoming).

I4 Cf., Nietzsche's subtle remarks on 'cheerfulness' in Schopenbauer as Educator, where he describes a "a cheerfulness that really cheers," in contrast to more superficial varieties (UM, III:2). We see the same sort of distinction at work when Nietzsche scorns the contentment of the 'last man' (TSZ, "Prologue"), while nonetheless praising a more hard-won form of cheerfulness on the part of others. As Nietzsche puts it in UM III:2, describing the more genuine kind of "cheerfulness that really cheers," "at bottom there is cheerfulness only where there is a victory."
} 
"last man" is an example of such a type (TSZ, "Prologue"). The great individual will be one who has faced difficulties, even faced great suffering, but still manages to be cheerful in the face of this. His opposite is the resentful person who goes through life in a foul mood, spreading his misery to others. ${ }^{15}$ According to Nietzsche, one of the most destructive features of Judeo-Christian morality, and its emphasis on compassion for suffering, is that it undermines this sort of joy by bringing misery to the fore and making people think that they have no right to be happy when others are suffering such misfortune. If the consciences of the strong get "poison[ed" with the thought of this alleged injustice, they will become ashamed of their good fortune and begin to "doubt their right to happiness" (GM, III:I4).

\section{Self-reverential}

In addition to holding life in high regard, great individuals hold themselves in high regard. "The noble soul," Nietzsche writes, "has reverence [Ehrfurcht] for itself" (BGE, 287; Cf., GS, 284). This is not to say that anyone with self-reverence is thereby a noble soul. Lots of deluded narcissists have a great deal of self-reverence. But the great individual is one who reveres himself and, importantly, whose characteristics merit this reverence. Such a person will not go in for false modesty, but certainly won't go in for unnecessary degrees of self-deprecation either. Nor will he go in for moralities of "un-selfing" [Entselbstung] that see the self as something to be escaped. On the flipside of self-reverence, we have self-dissatisfaction. But it is entirely appropriate for many to be dissatisfied with themselves. Even the great should be dissatisfied with themselves in some circumstances, for example when they've not lived up

\footnotetext{
${ }_{15}$ "There is among them an abundance of the vengeful disguised as judges, who constantly bear the word 'justice' in their mouths like poisonous spittle, always with pursed lips, always ready to spit upon all who are not discontented but go their way in good spirits" (GM III:I4).
} 
to an ideal. And for those working toward self-cultivation, dissatisfaction can be what powers one forward toward improvement. ${ }^{16}$ If self-dissatisfaction becomes a persistent state, though, it can have deforming effects on one's character: "Whoever is dissatisfied with himself is continually ready for revenge, and we others will be his victims, if only by having to endure his ugly sight. For the sight of what is ugly makes one bad and gloomy" (GS, 290).

\section{Aesthetically-appealing}

As this mention of the threat of ugliness will suggest, Nietzsche puts considerable emphasis on aesthetic considerations. The great person is going to be aesthetically-appealing, not just in physical terms (though maybe in that way too), but in being the sort of person with an alluringly stylish character. Such a person, one "who has turned out well," is one who is "carved from wood that is hard, delicate, and at the same time smells good" (EH, "Wise, 2). Nietzsche, likewise, speaks of the potential "splendor" [Pracht $]$ of the type man, which morality may be impeding (GM, "Preface," 6), further emphasizing this aesthetic dimension. Moreover, Nietzsche compares lives to works of art, with the suggestion that impressive lives share certain features with works of art (GS, 290, GS, 299). While some of these aesthetic characteristics will be external, there is a close interrelation between these outward manifestations and the qualities of one's soul. One does not simply present a pleasant outward face; one has a kind of unity or integration among one's drives, a condition that might usefully be

\footnotetext{
I6 See UM, III:6, where Nietzsche describes how an "exemplar" can enable a "consecration to culture:" "the sign of that consecration is that one is ashamed of oneself without any accompanying feeling of distress, that one comes to hate one's own narrowness and shriveled nature, that one has a feeling of sympathy for the genius who again and again drags himself up out of our dryness and apathy and the same feeling in anticipation for all those who are still struggling and evolving, with the profoundest conviction at almost everywhere we encounter nature pressing towards man and again and again failing to achieve him, yet everywhere succeeding in producing the most marvelous beginnings, individual traits and forms: so that the men we live among resemble a field over which is scattered the most precious fragments of sculpture where everything calls to us: come, assist, complete, bring together what belongs together, we have an immeasurable longing to become whole."
} 
thought of as aesthetic. The success (or failure) of this integration can be evident in one's characteristics. As in Nietzsche's example above, the person who hates himself will be marred by a kind of ugliness, if not in the literal visual sense, then in the kind of spiritual condition his persona evinces.

\section{Self-shaped}

Although some of this aesthetic appeal may be fortuitous, Nietzsche makes clear that it is something at which one has to work. It is a "great and rare art" to "give style" to one's "character" (GS, 290) in this way. This happens when one formulates an "artistic plan" for the self, and fits the various pieces together according to it, thereby creating a unified style. In this vein, Nietzsche talks about self-creation, an idea that can seem to court paradox. In what sense is a self being created, when this sort of artistic plan is being followed? This seems to raise a kind of regress problem. Who, after all, is doing the creating? The very self being created? I don't propose to go into detail about Nietzsche's views on the self and on freedom of the will, both being a minefield of difficulties. ${ }^{17}$ At minimum, though, we can allow that one has scope for making certain aesthetic choices and thereby determining, to some extent, how one's life goes, viewed through this aesthetic lens. This is all that is required for a less ambitious kind of aesthetic self-creation. To say that one exerts an influence in this way is not to presuppose libertarian free will or a blank canvas that can be filled in entirely as one wishes. (On these issues, see GS, 335; BGE, 225; TI, "Skirmishes," 49).

\footnotetext{
${ }^{17}$ A good overview of the debate, and proposal for a middle ground position, can be found in R. Lanier Anderson, "What is a Nietzschean Self," in Nietzsche, Naturalism, and Normativity, ed. Christopher Janaway and Simon Robertson (Oxford: Oxford University Press, 20I2). See also Sebastian Gardner, "Nietzsche, the Self, and the Disunity of Philosophical Reason," in Nietzsche on Freedom and Autonomy, ed. Ken Gemes and Simon May (Oxford) and Alexander Nehamas, "Nietzsche, Intention, Action," European fournal of Philosophy 26, no. 2 (2018): $685^{-7}$ OI.
} 
Integrated in their manifold drives and impulses (BGE 2I2, GS, 290; TI, "Skirmishes," 49)

Nietzsche's aesthetics is classical in spirit, in the emphasis it puts on integration above all else. ${ }^{18}$ This unity is not merely at the surface, but cuts much more deeply in the organization of one's underlying drives. Given the sort of creatures we are, we have a range of drives pulling in different directions. But in the great individual, these will be hierarchically organized, so that there is an (appropriate) dominant drive ruling over the other drives and turning them toward its purpose. This brings about a kind of wholeness, such that greatness of man is to be found in his "range and multiplicity, in his wholeness in manifoldness" (BGE, 212). ${ }^{19}$

\section{Possessed of an "instinct" for "cleanliness"}

Finally, one of the most distinctive characteristics Nietzsche mentions is an "instinct" for "cleanliness" (BGE, 27I). There is something almost boy-scout-sounding about this characteristic if we take it literally. But Nietzsche mainly means it in a more metaphorical register, resonating with several of the characteristics we have already discussed. In epistemic terms, cleanliness is a matter of intellectual honesty, particularly with one's self. It is, in aesthetic terms, a matter of the characteristic reaction that the great person has to those who are illconstituted. Nietzsche writes of himself that his "instinct for cleanliness is characterized by a perfectly uncanny sensitivity so that the proximity or-what I am saying-the inmost

\footnotetext{
I8 For further discussion of Nietzsche's commitment to unity, see Ken Gemes, "Nietzsche's Use and Abuse of Postmodernism," Philosophy and Phenomenological Research 62, no. 2, (200I): 337-60.

19 Richardson, Nietzsche's System; Ken Gemes, "Nietzsche and Freud on Sublimation," Fournal of Nietzsche Studies 38, no. I, 38-59 (2009); Christopher Janaway, "Nietzsche on Morality, Drives, and Human Greatness," in Nietzsche, Naturalism, and Normativity, ed. Christopher Janaway and Simon Robertson (Oxford: Oxford University Press, 20I2).
} 
parts, the "entrails" of every soul are physiologically perceived by me-smelled" (EH, "Why I Am So Wise," 8). He is thus able to find the "abundant bidden dirt at the bottom of many a character" (EH, "Why I Am So Wise," 8) and to stay away when necessary.

\section{Relation to Aristotle}

In his seminal 1950 book Nietzsche: Philosopher, Psychologist, Antichrist, Walter Kaufmann made the influential suggestion that Nietzsche's great-souled person is importantly similar to the Aristotelian megalopsychos. ${ }^{20}$ Kaufmann wrote this study in the wake of the Second World War, at a time when Nietzsche's reputation was in tatters. He sought to rehabilitate Nietzsche by showing that his philosophy was continuous with a tradition of humanism, and not the proto-Nazi celebration of ruthless power that it was often taken to be at the time. It is as part of this endeavor of rehabilitation that Kaufmann tries to show the affinities between Nietzsche and Aristotle. ${ }^{21}$ Though Kaufmann's intentions were noble, and his readings often astute, he had a tendency to overplay his hand. Many studies over the half past century have reacted to aspects of Kaufmann's reading, showing the way he presents an overly rosy picture of Nietzsche. On the topic of the great-souled person in particular, both Aristotle scholars and Nietzsche scholars have resisted Kaufmann's comparison between Aristotle and Nietzsche as unilluminating and superficial. ${ }^{22}$ But, to my mind, Kaufmann's

\footnotetext{
20 Walter Kaufmann, Nietzsche: Philosopher, Psychologist, Antichrist (Princeton: Princeton University Press, 1950 [1974]), 82-3. Cf., the useful discussion of this issue in Leiter, Nietzsche on Morality, 97.

${ }_{21}^{2}$ The megalopsychos may himself seem slightly suspect from a modern moral perspective. But Kaufmann, in framing this comparison, is trying to show that the Nietzschean great-souled person is not really all that bad.

${ }^{22}$ From the perspective of Aristotle scholarship, see Daniel Russell, "Aristotle's Virtues of Greatness," in Oxford Studies in Ancient Philosophy Supplementary Volume, ed. Rachana Kamtekar (Oxford: Oxford University Press, 2012). From the perspective of Nietzsche scholarship, see Bernd Magnus, "Aristotle and Nietzsche: 'Megalopsychia' and 'Übermensch" in The Greeks and the Good Life, ed. David J. Depew (Fullerton: California State Fullerton Press, 1980).
} 
suggestion has more going for it. There are certainly notable divergences between Aristotle and Nietzsche. But scholars have been too quick to dismiss the parallel, and have done so based on a misunderstanding and mischaracterization of Nietzsche's views on reason and rationality. I will begin by drawing out some of the key points of parallel and then will then proceed to answer the skeptical objections that have been leveled.

Before we get to the level of specific characteristics, the first thing to note is the similarly high position that this figure of the "great-souled" person occupies in the esteem of Aristotle and Nietzsche respectively. For Aristotle and for Nietzsche, it is a person who is flourishing and is doing so to an exceptional degree. Aristotle will describe this greatness of soul as a "crowning" virtue, or, as it is also translated, an "adornment" of the virtues (NE, II24a). For both Nietzsche and Aristotle, this is a rare condition. It is not a virtue that is in everyone's reach. ${ }^{23}$ But matters go considerably beyond this to include some of the more specific characteristics of the people in question. Consider some of the central features of the Aristotelian megalopsychos, as discussed in Book IV of the Nicomachean Ethics:

\section{High (justified) self-regard.}

This is a person who holds himself in high esteem, thinking himself "worthy of great things" (NE, II23b). But, importantly, such a person is warranted in doing so. "What he thinks he is worthy of accords with his real worth" (NE, II23b). Others (the vain, the humble) think too

\footnotetext{
${ }_{23}$ Nietzsche believes (perhaps unfairly) that Christianity praises virtues suited to the lowest common denominator, such as meekness and humility, which are virtues even the basest person can have. This, as I say, is somewhat unfair, since certain Christian virtues are extremely (maybe impossibly) demanding. An important theme in certain strands of Christian moral psychology is that it is extremely difficult to be truly humble. One's vanity will creep in and one will do things for the wrong reasons. Similarly demanding are the exhortations to love one's neighbor as oneself and to turn the other cheek when wronged.
} 
much or too little of themselves, where this is not justified by their capacities and accomplishments.

\section{Less regard for (most) others.}

Coupled with this high self-regard, the megalopsychos will also not think much of most other people. ${ }^{24}$ But his belief, according to Aristotle, is accurate. "For the magnanimous person is justified when he thinks less of others, since his beliefs are true" (NE, II24b). He won't be flaunting this distance in an arrogant way (NE, II24b), but one will have a self-assured sense that he is above others, and will not be ashamed about this, nor afraid to assert it in the right circumstances.

\section{Concern with significant tasks}

This is a person, Aristotle tells us, who will do a few well-chosen significant actions, not a number of insignificant small ones. "His actions are few, but great and renowned" (NE, II24b).

\section{Magnanimity (in the narrow sense)}

"He is not prone...to remember evils, since it is proper to a magnanimous person not to nurse memories, especially not of evils, but to overlook them" (NE, II25a).

\footnotetext{
${ }_{24}$ Cf. Nietzsche on this sense of being above others: "Without that pathos of distance which grows out of the ingrained difference between strata- when the ruling caste constantly looks afar and looks down upon subjects and instruments and just as constantly practices obedience and command, keeping down and keeping at a distance - that other, more mysterious pathos could not have grown up either-the craving for an ever new widening of distances within the soul itself, the development of ever higher, rarer, more remote, further stretching, more comprehensive states - in brief, simply the enhancement of the type 'man,' the continual 'self-overcoming of man' (BGE, 257).
} 


\section{Independence}

He is independent of the opinions of (most) others. "He cannot let anyone else, except a friend, determine his life. For that would be slavish; and this is why all flatterers are servile and [why] inferior people are flatterers" (NE, II25a). He "stays away from what is commonly honored" (NE, II24b). As Nietzsche might have put it, he is above herdish opinions, or honors conferred by the herd.

\section{Courage}

He "faces dangers in a great cause, and whenever he faces them he is unsparing of his life, since he does not think life at all costs worth living” (NE, II24b).

\section{Honesty}

He is concerned for truth more than for people's opinions. He is also honest with himself and honest with others, for example, "open in his hatreds...since concealment is proper to a frightened person" (NE, II24b).

We thus see a number of notable similarities between the Nietzschean great-souled individual and the Aristotelian megalopsychos. So why then is the Nietzschean great-souled individual thought to be so markedly different? The main line of objection focuses on the role of reason in Aristotle's conception of the virtuous life. For Aristotle, rational activity is the good of man, and he similarly puts a considerable emphasis on rationality, as manifested in prudence/ practical wisdom (phronesis). But Nietzsche, the objection continues, is dubious about the value of reason and rationality. While there is some truth in this, the point, I be- 
lieve, has been overstated, and makes the divergences between Aristotle and Nietzsche appear greater than they in fact are. The charge of "irrationalism" is one often put against $\mathrm{Ni}^{-}$ etzsche. But it is a caricature of his nuanced view. It plays into the idea that Nietzsche's human ideal is that of a kind of borderline wild-animal, the pillaging noble described in the First Essay of the Genealogy. But Nietzsche recognizes that we are far more interesting, complex, spiritual creatures at this juncture in history. Nietzsche is not against practical wisdom and rationality as such. He is against an i) overestimation of their significance; against ii) misunderstandings of what they amount to; and against the iii) perverse shapes they can sometimes take.

One reason for holding that Nietzsche is an anti-rationalist is that he emphasizes the role of the unconscious. Some might accordingly be drawn toward the interpretation that he thinks conscious ratiocination is just a screen for processes going on at an unconscious level. This will sometimes be expressed in terms of a drive psychology: We think we are reaching a rational decision, but really our drives are doing all the work. There is considerable debate about what exactly Nietzsche's view on these issues is, and it is well-beyond the scope to adjudicate it here. ${ }^{25}$ But this, at least, needs to be accounted for: we are beings who think about what we do, and seem to have reasons for the courses of action we take, and engage in

${ }_{25}$ For different perspectives on this issue, see Richardson, Nietzsche's System; Gemes, "Nietzsche on Free Will, Autonomy, and the Sovereign Individual"; Gemes, "Nietzsche and Freud on Sublimation"; Tom Stern, “'Against Nietzsche's 'Theory' of the Drives," Fournal of the American Philosophical Association I, no. I, I21-40; Paul Katsafanas, The Nietzschean Self. Nietzsche no doubt wants to stress the basic continuity between other animals and humans, and to reign in the pretensions of humans to think that they are somehow special. He also wants to dethrone the conscious ego as supreme master in the human psyche. All of these are welcome philosophical insights. But the idea that we can adequately explain complex human behavior in reductive psycho-biological terms, if this was indeed Nietzsche's theoretical view (and is indeed the view being attributed to him by some interpreters), seems to me crude and misguided - not to mention at odds with the rich psychological explanations that Nietzsche actually gives. Here the agent's own conceptualization of what they are doing, and the contextualization of that understanding in a social, historical, and cultural context, is going to be an important part of the explanatory story. That is not an argument I will make here, however. 
intelligible and intelligent patterns of action. Often (as Nietzsche pointedly stresses) people are self-deceived about their reasons for action, or engaged in various post-hoc rationalizations. But in those honest with themselves, as the great-souled individual will be, this should be at a minimum. Rationality needn't be understood as an autonomous efficacious force or a mysterious transcendental capacity, nor need it be operative only at the conscious level. It is what enables us to act in intelligent and intelligible ways as human beings. Nietzsche is not denying the self-evident truth that it possible and desirable to be rational in this sense. His points are always more subtle. Consider this passage, sometimes wrongly cited as evidence for Nietzsche's opposition to prudence:26

...If a man is praised today for living "wisely" [weise] or "as a philosopher," it hardly means more than "prudently $[k l u g]$ and apart." Wisdom seems to the rabble a kind of escape, a means and trick for getting well out of a wicked [schlimme] game. But the genuine philosopher—as it seems to us, my friends? — lives "unphilosophically" and "unwisely," above all $\mathrm{im}^{-}$ prudently [unklug] and feels the burden and the duty of a hundred attempts and temptations of life-he risks bimself constantly, he plays the wicked game (BGE, 205).

If we cherry-pick a phrase out of context, Nietzsche does seem to praise imprudence here. But this passage needs to be scrutinized carefully, rich as it is in inverted commas and wordplay. Nietzsche takes one conception of the philosophical life and, to it, juxtaposes another. One, he suggests, is borne of a desire for escape and an overabundance of caution. (He has perhaps in mind the Epicurean's retreat to cultivate his garden.) He wants, by contrast, a

\footnotetext{
${ }^{26}$ See Daniel Russell, “Aristotle's Virtues of Greatness,” 134-5.
} 
philosopher who is an experimenter, willing to take risks. This makes him "unwise" and "imprudent," relative to one cautious standard of wisdom and prudence. But it does not mean that the Nietzschean philosopher doesn't have a different sort of wisdom and prudence of his own. Nietzsche is a person, after all, who entitles major sections of his autobiography Ecce Homo "Why I Am So Wise [weise]" and "Why I am So Prudent/Clever [klug]."

Further apparent evidence for Nietzsche's alleged opposition to rationalism comes from his criticism of Socrates, in Nietzsche's words, a "buffoon" who makes reason a "tyrant" and who counsels that we be "absurdly rational" (TI, "The Problem of Socrates"). What Nietzsche would seem to have as his target in these remarks is not rationality per se, but an extreme version of it. It is sort that seeks, in the relentless way that Socrates does, to justify dialectically (often with quite specious arguments) virtually everything that he believes and holds dear. Nietzsche sees this as perverse and futile (TI, "Socrates," 5). But Nietzsche is not advocating that one behave irrationally, ignoring all considerations in favor of doing or believing things, nor is he suggesting abandoning oneself wholly to blind impulse. He challenges a perverse idea of what rationalism would be, not the idea that rationality [Vernunft $]$ has an important role to play. Rationality (or Reason) [Vernunft $]$ is, after all, something Nietzsche includes with "virtue, art, music, dance...[and] spirituality" as among the things "for whose sake it is worth while to live on earth" (BGE, I88).

Of course, there are major differences between Nietzsche and Aristotle. For the latter, rationality occupies an especially prominent role. The ergon (function) of the human being just is rational activity in accordance with virtue (NE, 1097b-1098a), and Aristotle sees human flourishing as realized through fulfilling this ergon. Nietzsche will part ways at this point, not, however, because he is an irrationalist, but instead because he thinks human na- 
ture and the human good is less closely tied to rationality and rational activity per se. This is compatible with thinking, as Nietzsche evidently does, that reason and rationality still have a central place in the well-ordered soul, in conjunction with other traits and virtues. The distance between Nietzsche and Aristotle on this front, while significant, has nonetheless been exaggerated, based on a misreading of Nietzsche.

But there is still another salient difference, and I want to close by discussing that. On Nietzsche's view, the great individual could, it would seem, be a profoundly immoral person, whereas this is not true of Aristotle, for whom being magnanimous requires also being "fine and good" (NE, II24a). Greatness of soul and morality are yoked closely together in Aristotle; in Nietzsche, they can come apart.

Of course, some of the traits that Nietzsche celebrates haven't always been as morally suspect as they are in the Judeo-Christian tradition, and some of the things he attacks haven't always been as celebrated. Pride has not always been a vice, nor has humility always been a virtue, as reflection on Aristotle shows. ${ }^{27}$ But could a deeply immoral person be great, in Nietzsche's eyes? I think Nietzsche's answer is pretty clearly yes. Cesare Borgia and Napoleon left many dead in their self-aggrandizing wake. And yet, far from debarring them from being great, one suspects that this is not, for Nietzsche, an obstacle; if anything, some of their nastier traits advance their claim to Nietzschean greatness. ${ }^{28} \mathrm{~A}$ more subtle question is whether they can be great of soul, not just in influence or effect. Although Nietzsche does

\footnotetext{
${ }_{27}$ Cf. Howard Curzer, "Aristotle's Much-Maligned Megalopyschos," Australasian fournal of Philosophy 69, no. 2 (I99I): $13 \mathrm{I}^{-} 5 \mathrm{I}$ for a different perspective on the relation between this Aristotelian virtue and Christianity, I48 ${ }^{-9}$.

${ }_{28}^{28}$ For a good discussion of these issues, see Nehamas, "Nietzsche and 'Hitler," Southern fournal of Philosophy 37 Supplement (1999): $\mathrm{I}^{-} \mathrm{I} 7$.
} 
not give us clear textual indication one way or the other, one suspects his answer would still be yes. He certainly does not include a morality constraint.

Even so, it is vital to see that it is not the mere fact that they perpetrate immoral deeds that speaks to their greatness. One of the ways in which Nietzsche is most often misunderstood, by adolescents and the adolescently-minded, is that you become great or otherwise prove yourself great just by doing something (maybe anything) deeply immoral and thereby demonstrating that you are above the sort of morality that constrains everyone else. This, it might be thought, is roughly the Leopold and Loeb understanding of Nietzsche. But simply murdering someone for sport, or proving yourself able to do so, is not sufficient for being great (particularly of soul). Nonetheless, it would appear that there are morally objectionable people that Nietzsche would regard as great, and not just coincidentally great, but great partly thanks to some of their features that are morally suspect. Whatever qualms we might have about this view, it pretty clearly is Nietzsche's. If one is to view and use others in instrumentalizing ways, or to regard their suffering with callousness, to be devoted in a single-minded way to a personal project when one could be focused on the common weal, or to affirm all of existence (including the questionable and terrible aspects), morality (as conceived by the Judeo-Christian tradition and its secular expressions), must not be one's overriding focus of concern.

The question I want to close on is a different one, namely this: Granted, some great people are immoral. But need a great person be particularly immoral-that is, more immoral than the average person? If so, why? There are people who accomplish great things (more likely in art than in statecraft), without being ruthless or immoral about it, and often thanks to moral traits Nietzsche despises (a sense for the universal brotherhood of all humans, say). 
Why then, it might be supposed, is there any necessary sort of tension between morality and greatness? But this line of objection focuses just on great accomplishment. Nietzsche can allow that there are great accomplishments, even by those who are not themselves great individuals, or great of soul. Such individual greatness is valuable not simply a route to independent great accomplishments (e.g., writing the Eroica, defeating the Gauls). It is valuable for its own sake as well. The virtues and traits that Nietzsche cites are constitutive elements in the flourishing life. The person who lacks these sorts of traits (or has ones opposed to these) is leading a defective (or at least a non-ideal) life, in Nietzschean terms.The tension with the morality tradition is thus even more thoroughgoing than it might at first seem. Nietzsche is not just making an empirical claim about which traits which lead to the sorts of great things that Nietzsche values. His view of greatness and of greatness of soul is itself a conception of what an exceptionally good life amounts to. Judeo-Christianity holds out a certain ideal of great lives (e.g., the Christian saint, full of pity for the suffering mass of humanity), to which Nietzsche opposes a counter-ideal. In parts, it is very difficult to accept. We may well reject that ideal, or at least not want to subscribe to it fully. But Nietzsche does force us to think more critically about what we think makes for a great-souled person, and challenges us with a provocative vision of his own.

But for all his apparent radicalism, when it comes to greatness of soul, Nietzsche is less starting from scratch with an entirely new theory, but is in large part borrowing aspects of a classical tradition that he sees Judeo-Christianity as in danger of obscuring. That said, Nietzsche is a highly historical thinker. He doesn't simply want us to return to a Homeric outlook, or to an Aristotelian outlook, or anything of the kind. But he thinks we can take important lessons for how we might move forward in the modern era, and think about the 
shape a "great soul" might take in these changed conditions. That is among the tasks he sets himself in Beyond Good and Evil, and his other towering contributions to philosophical ethics. ${ }^{29}$

29 My gratitude to Ken Gemes, Alexander Nehamas, David Carr, and Sophia Vasalou for comments on the ideas I discuss here, as well as to an audience at the "Virtues of Magnanimity" Conference at the University of Birmingham and to two anonymous referees. 


\section{Works Cited}

Works by Nietzsche are cited by section number using the following abbreviations and translations, which I have modified where I've thought appropriate:

$\mathrm{A}=$ The Antichrist. Translated by Walter Kaufmann. New York: Penguin Books, I954.

BGE = Beyond Good and Evil. Translated by Walter Kaufmann. New York: Vintage Books, 1966.

$\mathrm{EH}=$ Ecce Homo. Translated by Walter Kaufmann. New York: Vintage Books, 1967.

GM = On the Genealogy of Morals. Translated by Walter Kaufmann. New York: Vintage Books, 1967/ On the Genealogy of Morality. Translated by Maudemarie Clark and Alan Swensen. Indianapolis: Hackett Books, I998.

GS = The Gay Science. Translated by Walter Kaufmann. New York: Vintage Books, 1974 .

$\mathrm{HH}=$ Human, All Too Human. Translated by R.J. Hollingdale. Cambridge: Cambridge University Press, 1986.

TI = Troilight of the Idols. Translated by Walter Kaufmann. New York: Penguin Books, 1954 . TSZ = Thus Spoke Zarathustra. Translated by Walter Kaufmann. New York: Penguin Books, I954.

UM = Untimely Meditations. Translated by R.J. Hollingdale. Cambridge: Cambridge University Press, 1997.

WP = The Will to Power. Translated by Walter Kaufmann and R. J. Hollingdale. New York: Vintage Books, 1967.

In works that comprise several individual essays, after the abbreviation is the essay number (as a Roman numeral) and section number (as an arabic numeral). For example, GM, I:2 is On the Genealogy of Morals, Essay I, Section 2. In works that include titled main sections, I include a key word for that section, followed by subsection numbers, if applicable. For example, TI, "Socrates," I is the Trilight of the Idols section "The Problem of Socrates," subsection $\mathrm{I}$.

For the German I rely on the following, cited by volume and page number.

KSA $=$ Kritische Studienausgabe, edited by Giorgio Colli and Mazzino Montinari. Berlin: de Gruyter, 1967 .

I cite Aristotle's Nicomachean Ethics in the translation by T.E. Irwin (Indianapolis: Hackett, 2000) using the standard Bekker numbers.

***

Anderson, R. Lanier. "What is a Nietzschean Self." In Nietzsche, Naturalism, and Normativity, edited by Christopher Janaway and Simon Robertson. Oxford: Oxford University Press, 2012.

Curzer, Howard. "Aristotle's Much-Maligned Megalopyschos." Australasian fournal of Philosophy 69, no. 2 (199I): 131-5I. 
Gardner, Sebastian. "Nietzsche, the Self, and the Disunity of Philosophical Reason." In Nietzsche on Freedom and Autonomy, edited by Ken Gemes and Simon May. Oxford: Oxford University Press, 2009.

Gemes, Ken. "Nietzsche's Use and Abuse of Postmodernism." Philosophy and Phenomenological Research 62, no. 2 (2001): 337-60.

Gemes, Ken. "Nietzsche on Free Will, Autonomy, and the Sovereign Individual." In Nietzsche on Freedom and Autonomy, edited Ken Gemes and Simon May. Oxford, Oxford University Press, 2009.

Gemes, Ken. "Nietzsche and Freud on Sublimation." Fournal of Nietzsche Studies 38, no. I (2009): $38^{-59}$.

Hassan, Patrick. "Nietzsche on Human Greatness." Fournal of Value Inquiry 5I, no. 2 (20I7): 293-3IO.

Huddleston, Andrew. "Nietzsche on the Health of the Soul." Inquiry 60, No. I-2 (20I7): I35-I64.

Huddleston, Andrew. Nietzsche on the Decadence and Flourishing of Culture. Oxford: Oxford University Press, 2019.

Huddleston, Andrew. "Affirmation, Admirable Overvaluation, and the Eternal Recurrence." In Nietzsche on Morality and Affirmation, edited by Daniel Came. Oxford: Oxford University Press, forthcoming.

Janaway, Christopher. "Nietzsche on Morality, Drives, and Human Greatness." In Nietzsche, Naturalism, and Normativity, edited by Christopher Janaway and Simon Robertson. Oxford: Oxford University Press, 2012.

Katsafanas, Paul. "Nietzsche's Philosophical Psychology." In Oxford Handbook of Nietzsche, edited by Ken Gemes and John Richardson. Oxford: Oxford University Press.

Katsafanas, Paul. The Nietzschean Self: Moral Pyschology, Agency, and the Unconscious. Oxford: Oxford University Press, 2016.

Kaufmann, Walter. Nietzsche: Philosopher, Psychologist, Antichrist. Princeton: Princeton University Press, I950 [1974].

Leiter, Brian. Nietzsche on Morality, 2nd Edition. London and New York: Routledge, 20 I4.

Magnus, Bernd. "Aristotle and Nietzsche: 'Megalopsychia' and 'Übermensch." In The Greeks and the Good Life, edited by David J. Depew. Fullerton, California State Fullerton Press, I980. 
Nehamas, Alexander. Nietzsche: Life as Literature. Cambridge, MA: Harvard University Press, 1985 .

Nehamas, Alexander. "Nietzsche and 'Hitler." Southern fournal of Philosophy 37 Supplement, II7.

Nehamas, Alexander. "Nietzsche, Intention, Action." European fournal of Philosophy 26, no. 2 (2018): 685-70I.

Reginster, Bernard. The Affirmation of Life: Nietzsche on Overcoming Nibilism. Cambridge, MA: Harvard University Press, 2006.

Richardson, John. Nietzsche’s System. Oxford: Oxford University Press, 1996.

Richardson, John. "Nietzsche's Freedoms." In Nietzsche on Freedom and Autonomy, edited by Ken Gemes and Simon May. Oxford: Oxford University Press, 2009.

Russell, Daniel. "Aristotle's Virtues of Greatness." Oxford Studies in Ancient Philosophy Supplementary Volume, edited by Rachana Kamtekar. Oxford: Oxford University Press, 2012.

Stern, Tom. "Against Nietzsche's 'Theory' of the Drives." Fournal of the American Philosophical Association I, no. I (2O15): 121-40.

Townsend, Simon. "Beyond the Myth of the Nietzschean Ideal Type." European Fournal of Philosophy 25, no. 3 (2017): 617-37. 